\title{
POLA PERTUMBUHAN BAKTERI ASAM LAKTAT SELAMA FERMENTASI SUSU KEDELAI
}

\author{
GROWTH PATTERN OF LACTIC ACID BACTERIA DURING SOY MILK FERMENTATION
}

\author{
Darimiyya Hidayati \\ Program Studi TIP, Fakultas Pertanian, Universitas Trunojoyo \\ Jl.Raya Kamal PO BOX 2 Kamal, Madura, Email : darimiyyahidayati@trunojoyo.ac.id
}

\begin{abstract}
Soy milk is a rich source of protein and unsaturated fatty acid, but soy milk is not widely accepted because of its beany flavor and the belief that it caused flatulence. Soy milk served as an excellent medium for the growth of lactic acid bacteria because they possess ability to utilize oligosaccharides (sucrose, raffinose, and stachyose) in soybean. The objective of this research was to study growth pattern of lactic acid bacteria in soy milk. 4 strains of lactic acid bateria were grown in soy milk for 24 hours. $p H$ and total LAB were analyzed every 3 hours. The result showed that Lactobacillus bulgaricus and Lacobacillus plantarum were able to use soy milk as growing medium, while Lactobacillus acidophilus and Strepococcus thermophilus could not grow well in soy milk.
\end{abstract}

Key words : lactic acid bacteria, growth pattern, soy milk

\begin{abstract}
ABSTRAK
Susu kedelai merupakan sumber kaya protein dan asam lemak tidak jenuh tetapi kurang diterima secara luas karena rasa dan kepercayaan masyarakat bahwa susu kedelai dapat menyebabkan flatulensi. Susu kedelai merupakan medium yang baik untuk pertumbuhan bakteri asam laktat karena kemampuan dalam pemanfaatan oligosakarida (sukrosa, raffinosa dan stakiosa) pada kedelai. Tujuan penelitian ini adalah untuk mempelajari pola pertumbuhan bakteri asam laktat pada susu kedelai. 4 strain bakteri asam laktat ditumbuhkan pada susu kedelai selama 24 jam. $\mathrm{pH}$ dan total bakteri asam laktat dianalisis setiap 3 jam. Hasil penelitian memnunjukkan bahwa Lactobacillus bulgaricus dan Lactobacillus plantarum mampu memanfaatkan susu kedelai sebagai medium pertumbuhan sedangkan Lactobacillus acidophillus dam Streptococcus thermophillus tidak dapat tumbuh dengan baik dalam susu kedelai.
\end{abstract}

Kata kunci : bakteri asam laktat, pola pertumbuhan, susu kedelai

\section{PENDAHULUAN}

Kedelai merupakan sumber protein nabati bagi penduduk dunia, khususnya penduduk dinegara-negara berkembang. Selain kandungan protein tinggi, kedelai juga mengandung mineral, vitamin serta asam lemak tidak jenuh yang dapat mencegah atherosklerosis (Smith dan Circle, 1972). Kadar protein berbagai varietas kedelai yang ada di Indonesia berkisar 30,53 - 44,00\% (Koswara, 1992)

Produk-produk makanan dari kedelai kurang diterima oleh konsumen karena umumnya memiliki bau langu (beany flavour) dan menyebabkan flatulensi. Bau langu disebabkan oleh peroksidasi asam lemak tidak jenuh atau pembentukan ester yang dikatalis oleh enzim lipoksigenase (Liu, 1999). Senyawa volatil yang dihasilkan adalah keton, aldehid, alkohol dan senyawa lain yang dapat menimbulkan flavor yang tidak diinginkan.
Flatulensi disebabkan kandungan rafinosa dan stakiosa kedelai relatif tinggi. Hidrolisis kedua oligosakarida tersebut membutuhkan dua enzim yaitu enzim invertase (E.C 3.2.1.26) untuk menghidrolisis sukrosa dari oligosakarida dan enzim $\alpha$ galaktosidase (E.C 3.2.21) yang dibutuhkan untuk menghidrolisis ikatan $\alpha$-galaktosida (Mital dan Steinkraus, 1975). Dalam saluran pencernaan manusia, enzim $\alpha$-galaktosidase tidak ada sehingga oligasakarida tersebut tidak dapat diserap dan selanjutnya dimanfaatkan oleh mikroflora di usus besar dan menghasilkan gas yang menyebabkan flatulensi.

Salah satu pemanfaatan kedelai adalah produk susu kedelai yang memiliki total padatan sekitar 8-10\% tergantung perbandingan antara air dan kedelai kering pada proses pembuatannya. Susu kedelai dapat memenuhi kebutuhan potein untuk masyarakat yang tidak bisa mengkonsumsi 
susu hewani karena alasan kesehatan ataupun ekonomi. Selain itu, susu kedelai bebas kolesterol dan kandungan asam lemak tidak jenuhnya tinggi sehingga bermanfaat bagi kesehatan. ( Liu, 1999 dan Yusmarini, 1998).

Susu kedelai masih memiliki bau langu dan juga dapat menyebabkan flatulensi sehingga kurang diterima oleh konsumen. Fermentasi dapat meningkatkan kenampakan, flavor atau aroma susu kedelai sehingga diharapkan dapat lebih diterima oleh konsumen (Mital dan Steinkraus, 1974 ;Koswara, 1992). Bakteri asam laktat yang berperan penting pada berbagai macam makanan fermentasi juga bisa menggunakan susu kedelai sebagai medium pertumbuhannya. Beberapa bakteri asam laktat mempunyai kemampuan untuk menggunakan sukrosa (gula utama pada kedelai) sebagai sumber energi dan mempunyai enzim $\alpha$-galaktosidase sehingga dapat menghidrolisis rafinosa dan stakiosa (Mital dan Steinkraus, 1974; Mital dan Steinkraus, 1975; Yusmarini, dkk., 1998).

Produk-produk fermentasi dari susu kedelai umumnya diadaptasi dari produk fermentasi dari susu hewani. Beberapa produk fermentasi dari susu kedelai antara lain yogurt susu kedelai/soygurt (Cheng, dkk., 1990; Yusmarini, dkk., 1998) dan produk keju krim tiruan menggunakan bakteri L. casei (Hofman dan Marshal, 1985).

Kendala yang dihadapi selama ini adalah masih terbatasnya informasi tentang pola pertumbuhan bakteri asam laktat selama fermentasi susu kedelai dan strain bakteri asam laktat yang mampu tumbuh pada susu kedelai. Informasi ini sangat penting diperlukan untuk menentukan kondisi fermentasi yang paling tepat dalam menghasilkan soygurt yang berkualitas. Oleh karena itu, perlu dilakukan penelitian tentang pola pertumbuhan beberapa bakteri asam laktat dalam fermentasi susu kedelai.

\section{METODE PENELITIAN}

\section{Bahan}

1. Isolat Bakteri Asam Laktat

Isolat bakteri asam laktat diperoleh dari isolasi dari bahan sesuai Tabel 1.

2. Kedelai

3. Bahan-bahan kimia

Bahan kimia yang digunakan dalam penelitian adalah MRS (Man-RogosaSharpe, Merck), skim milk, dan gliserol

\section{Alat}

Peralatan utama yang digunakan dalam penelitian ini adalah autoclave, $\mathrm{pH}$ meter, Quebec Colony Counter, dan mikroskop.

\section{Metode}

a. Pembuatan susu kedelai

Pembuatan susu kedelai menggunakan metode Illinois yang dimodifikasi dengan penyaringan(Liu, 1999). Tahapan pembuatannnya meliputi perendaman kedelai dalam larutan $\mathrm{NaHCO}_{3}$ 0,5\% selama 12 jam, perebusan kedelai dalam larutan $\mathrm{NaHCO}_{3} \quad 0,5 \%$ selama 30 menit, penghilangan kulit dan pencucian, penghancuran dengan penambahan air hangat $\left( \pm 80^{\circ} \mathrm{C}\right)$ dan perbandingan kedelai kering:air $=1: 7$, dan penyaringan. Susu kedelai ditambah sukrosa sebanyak 8-10\%, kemudian disterilisasi pada suhu $115{ }^{\circ} \mathrm{C}$ selama 10 menit.

b. Fermentasi susu kedelai

Pertumbuhan bakteri asam laktat diamati dengan pengukuran nilai $\mathrm{pH}$ dan total BAL setiap 3 jam sekali selama 24 jam.

c. Metode Perhitungan Populasi Bakteri Asam Laktat

$1 \mathrm{ml}$ atau 1 gram sample diencerkan dalam beberapa seri pengenceran $\left(10^{-1}\right.$ sampai tingkat pengenceran tertentu). 3 seri pengenceran terakhir diplating pada media MRS agar $+1 \% \mathrm{CaCO}_{3}$ secara pour plate 
Tabel 1. Strain bakteri asam laktat yang digunakan dalam penelitian

\begin{tabular}{ccc}
\hline No & Strain Bakteri Asam Laktat & Sumber \\
\hline 1 & Lactobacilus bulgaricus & Starter yogurt \\
2 & Lactobacilus plantarum & Tempe \\
3 & Lactobacilus acidophilus & Dadih \\
4 & Streptococcus thermophilus & Starter yogurt
\end{tabular}

\section{HASIL DAN PEMBAHASAN}

Pertumbuhan bakteri asam laktat diamati dengan perhitungan jumlah BAL dan nilai $\mathrm{pH}$ setiap interval 3 jam selama 24 jam. Dari Gambar 1 menunjukkan bahwa ada kecenderungan peningkatan populasi BAL dan selanjutnya stationer sampai jam ke-24. Sedangkan nilai $\mathrm{pH}$ turun seiring dengan meningkatnya waktu fermentasi.

Pola pertumbuhan bakteri asam laktat pada fermentasi susu kedelai mempunyai pola yang berbeda-beda. Perbedaan ini disebabkan oleh kemampuan bakteri asam laktat dalam memanfaatkan sumber karbon yang terdapat dalam susu kedelai. Pola pertumbuhan L.bulgaricus dan S.thermophilus mempunyai kecenderungan yang hampir sama yaitu meningkat dari jam ke-0 sampai jam ke-12, kemudian cenderung stationer mulai jam ke-12 sampai jam ke-24. Hal ini menunjukkan bahwa L.bulgaricus dan S.thermophilus mencapai fase stasioner pada jam ke-12 selama fermentasi susu kedelai. Menurut Ngatirah (2000), L.bulgaricus memasuki fase logaritmik akhir (awal fase stationer) pada sekitar 16-18 jam untuk fermentasi di MRS broth pada suhu 37 ${ }^{\circ} \mathrm{C}$. Sedangkan Mital dan Steinkraus (1974) menyatakan bahwa L.bulgaricus mencapai fase stationer setelah 8 jam fermentasi pada susu kedelai yang ditambah dengan 2\% sukrosa.

Pola pertumbuhan L.plantarum dapat dilihat pada gambar (b). Pola pertumbuhannya tidak memberikan kurva pertumbuhan yang jelas. Populasi bakteri asam laktat meningkat seiring bertambahnya waktu fermentasi, dan mencapai puncaknya pada fermentasi 15 jam. Hal ini menunjukkan fase logaritmik L.plantarum adalah 0-15 jam dan selanjutnya cenderung mengalami penurunan (fase kematian). Menurut Mital dan Steinkraus (1975), L.plantarum memiliki enzim $\alpha$-galaktosidase sehingga dapat memecah ikatan $\alpha$-galaktosidik yang ada rafinosa dan stakiosa (karbon utama dalam susu kedelai).

Pola pertumbuhan L.acidophilus dapat dilihat pada gambar (c). Pola pertumbuhan dari bakteri ini juga tidak memberikan kurva pertumbuhan mikroorganisme yang jelas. Populasi bakteri asam laktat meningkat terus sampai lama fermentasi 21 jam, dan selanjutnya turun pada lama fermentasi 24 jam. Hal ini menunjukkan adanya fase logaritmik yang sangat panjang yaitu 21 jam lama fermentasi. Menurut Mital dan Steinkraus (1974), L.acidophilus mampu mengkonsumsi sukrosa dan glukosa, namun tidak dapat mengkonsumsi rafinosa dan stakiosa. Fase logaritmik yang panjang diatas menunjukkan bahwa bakteri ini membutuhkan waktu yang lama untuk beradaptasi dengan media susu kedelai.

Perbedaan jenis dan jumlah sumber karbon pada media sangat mempengaruhi pertumbuhan mikroorganisme sehingga pada pola pertumbuhan mikroorganisme akan berbeda pada media fermentasi yang berbeda. Sumber karbon pada MRS broth berupa glukosa sehingga dapat dimanfaatkan langsung oleh BAL. Sedangkan sumber karbon dalam susu kedelai adalah sukrosa, stakiosa dan raffinosa sehingga diperlukan enzim $\alpha$-galaktosidase untuk dapat menghidrolisisnya. Oleh karena itu, pola pertumbuhan bakteri asam laktat berbedabeda tergantung kemampuan bakteri tersebut dalam mengkonsumsi sumber karbon yang tersedia. Pertumbuhan bakteri asam laktat dalam susu kedelai lebih lambat dibandingkan dalam MRS broth karena perbedaan sumber karbon dalam kedua media tersebut. Selain itu, jumlah karbohidrat dalam susu kedelai sangat terbatas sehingga penambahan sukrosa harus cukup untuk meningkatkan pertumbuhan BAL. 


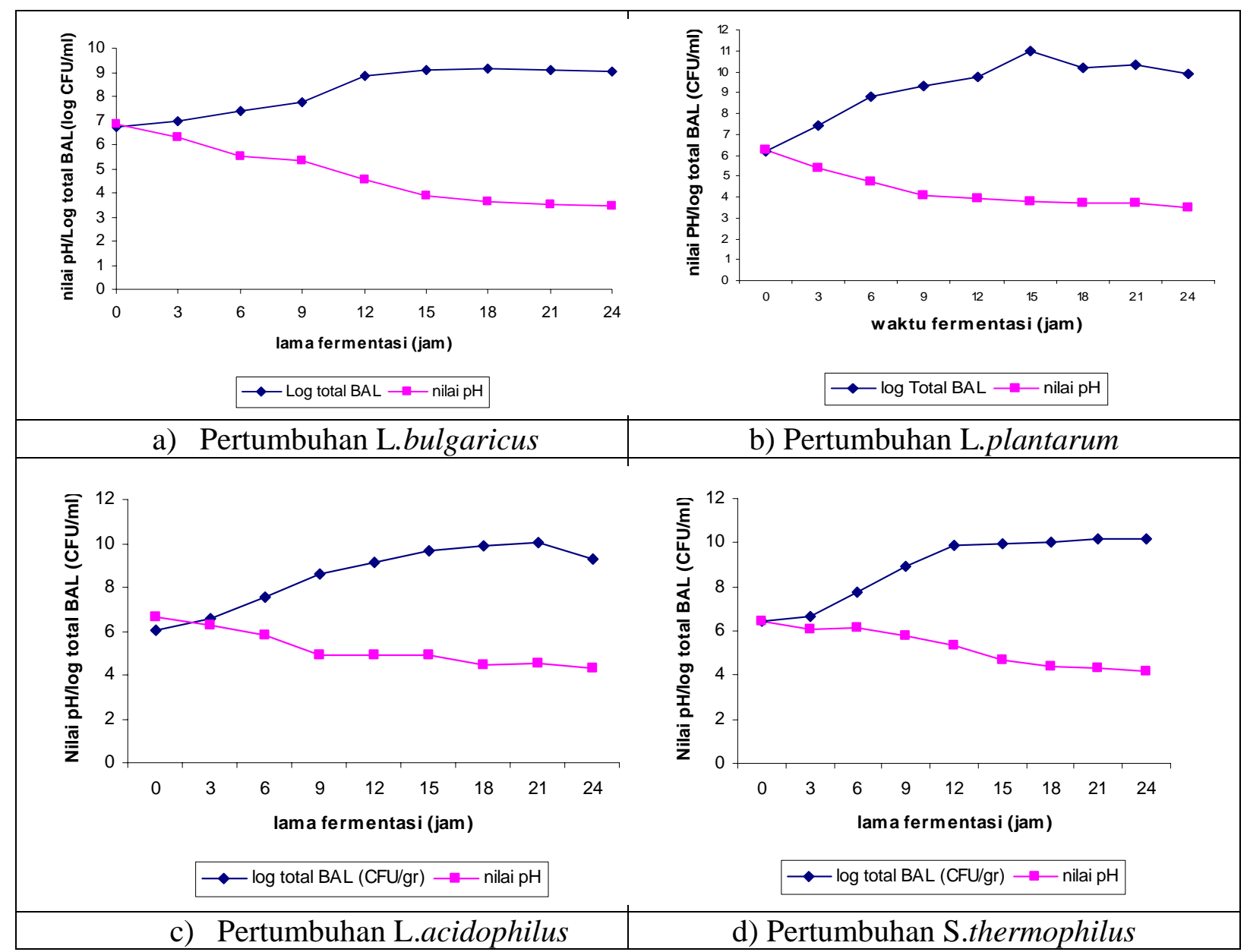

Gambar 1. Pertumbuhan bakteri asam laktat dalam susu kedelai

Nilai pH turun selama fermentasi karena adanya produksi asam laktat dari karbohidrat yang ada dalam susu kedelai. Nilai pH untuk L.bulgaricus dan L. plantarum pada jam ke-24 mencapai 3,43 dan 3,47 menunjukkan bahwa L.bulgaricus dan L.plantarum mampu tumbuh subur dan memproduksi asam laktat dalam susu kedelai dengan penambahan 8\% sukrosa. Berbeda dengan penelitian Mital dan Steinkraus (1974) yang menyatakan bahwa Lactobacilus bulgaricus tidak mampu tumbuh di susu kedelai yang diberi $2 \%$ sukrosa, ditunjukkan dengan nilai $\mathrm{pH}$ sekitar 6 pada akhir fermentasi 16 jam. Hal ini menunjukkan bahwa untuk fermentasi susu kedelai, diperlukan penambahan sukrosa atau glukosa yang cukup sebagai sumber energi bagi bakteri asam laktat karena karbohidrat yang ada di susu kedelai sangat terbatas. Sedangkan penelitian Mital dan Steinkraus (1974) menunjukkan bahwa L.plantarum mampu tumbuh di susu kedelai, ditunjukkan dengan nilai $\mathrm{pH}$ sekitar 4 pada akhir fermentasi 16 jam.

Sedangkan nilai $\mathrm{pH}$ untuk bakteri L.acidophilus dan S.thermophilus masih cukup tinggi yaitu sekitar 4 diakhir fermentasi 24 jam. Hal ini menunjukkan kemampuan kedua bakteri tersebut untuk tumbuh dalam susu kedelai kurang dibandingkan kedua bakteri pertama. Penelitian Mital dan Steinkraus (1974) menunjukkan bahwa L.acidophilus dan S.thermophilus tidak dapat menggunakan rafinosa dan stakiosa yang ditandai dengan nilai akhir $\mathrm{pH}$ yang masih tinggi (lebih dari 6).

\section{KESIMPULAN}

Berdasarkan penelitian dan pembahasan yang telah dilakukan, dapat disimpulkan bahwa : Pola pertumbuhan bakteri asam laktat dalam fermentasi susu kedelai tergantung dari kemampuan bakteri 
dalam mengkonsumsi sumber karbon (jumlah dan jenis) yang terdapat dalam susu kedelai. L.bulgaricus dan L.plantarum mampu tumbuh didalam fermentasi susu kedelai. L.acidophilus dan S.thermophilus kurang mampu tumbuh dalam fermentasi susu kedelai

\section{DAFTAR PUSTAKA}

Anonim.

(http://www.indomedia.com/intisari)

Atlas, R.M. 1997. Principles of Microbiology. Wm.C. Brown Publisher.

Bordignon, J.R., K.Nakahara, T. Yoshihashi, dan S. Nikkuni. 2004. Hidrolysis of Isoflavones an Consumption of Oligosaccaharides during Lactic Acid Fermentation of Soybean Milk. JARQ. 38(4):259-265

Cheng, Y.S., L.D. Thompson, dan H.C. Britin. 1990. Sogurt, A Yogurt like Soybean Product: Development Properties. J.Food Science. 55: 11781179

Garro, M.S, G.F.Valdez, G.Oliver, dan G.S. de Giori. 1999. Starter Culture Activity in Refrigerated Fermented Soymilk. J.food Protection. 62:808-810.

Hoffman, C.J. dan W.E. Marshal. 1985. Lactic Fermentation of Ground Soybean for Use in Imitation Cream Cheese Product. J.Food Science. 50:325-329

Koswara, S. 1992. Teknologi Pengolahan Kedelai. Pustaka Sinar Harapan. Jakarta.

Lee, S.Y., C.V. Morr, dan A.Seo. 1990. Comparison of Milk-Based and Soymilk-based Yogurt. J.Food Science. Vol 55:532-536

Liu, K. 1999. Soybeans: Chemistry, Technology, dan Utilization. Aspen Publisher, Inc. Gaithersburg, Maryland

Mital, B.K dan K.H. Steinkraust. 1974. Growth of Lactic Acid Bacteria in Soy Milks. J.Food Science. 39:1018-1022
Mital, B.K dan K.H. Steinkraust. 1975. Utilization of Oligosaccharides by Lactic Acid Bacteria During Fermentation of Soy Milk. J.Food Science. Vol 40: 114-118.

Rahayu, E.S. 2002. Lactic Acid Bacteria and Their Roles in Food Industries in Indonesia. Proceedings of the $4^{\text {th }}$ AsiaPacific Biotechnology Congress \& $30^{\text {th }}$ Annual PSM Convention

Salminem, S. dan A.V. Wright. 1998. Lactic Acid Bacteria (Microbiology and Functional Aspects. Marcel Dekker, Inc. New York.

Smith, A.K dan S.J. Circle. 1972. Soybean, Chemistry and Technology. AVI Publishing. Conecticut

Watkins, B.A dan Y.Li. 2002. Food Lipids: Chemistry, Nutrition, and Biotechnology. Marcel Dekker, Inc: New York

Yusmarini, M. Adnan, dan S. Hadiwiyoto. 1998. Perubahan Oligosakarida pada Susu Kedelai dalam Proses Pembuatan Yogurt. BPPS-UGM 